\title{
The Role of Quality in Higher Education and Lifelong Learning in Entrepreneurship Competencies of Undergraduate Students
}

\author{
Ali Asgari ${ }^{1}$, Hossein Shokouhi Fard ${ }^{2}$, Fatemeh Tirgoo ${ }^{3}$ \\ 1 Department of Educational Sciences, Faculty of Educational Sciences and Psychology, Birjand University, Birjand, \\ Iran, ali.asgari@birjand.ac.ir \\ 2 Department of Educational Sciences, Faculty of Educational Sciences and Psychology, Birjand University, Birjand, \\ Iran, hshokohi@birjand.ac.ir \\ 3 Department of Educational Sciences, Faculty of Educational Sciences and Psychology, Birjand University, Birjand, \\ Iran, fatemehtirgoo@gmail.com.
}

\begin{abstract}
The main objective of this research is to investigate the role of quality in higher education and lifelong learning competencies in entrepreneurship competencies of undergraduate students. The statistical population of this study was all undergraduate students. The descriptive correlational research method was used. For collecting data these questionnaires were used: the Liberal Entrepreneurship Competency Questionnaire (2007), Mantz Academic Quality in Higher Education (1995) and the Life-Long Learning of Wielkiewicz and Meuwissen (2014). The results showed that the entrepreneurial and lifelong learning competencies are at a good level. There is also a positive and significant relationship between lifelong learning and entrepreneurship competencies.
\end{abstract}

Keywords: Higher Education, Lifelong Learning, Entrepreneurial Competencies.

\section{Introduction}

In today's evolving world, when technologies are challenging human lives willingly or unwillingly, only societies with skillful, creative and self-assured workers would be successful, since nowadays, creative and innovative individuals, working as entrepreneurs, initiate great changes in the fields of industry, education, and services in the world arena. The entrepreneur is someone who is racing the frontiers of innovation, creates new 
processes for doing things, initiates new jobs, and organizes a new industry. Addressing entrepreneurship, training, and education of those graduates who have the demanding skills and abilities to start up a proper business is one of the main tasks of trainers at universities. Universities and educational institutions create structures for students' development of education by developing a tendency toward lifelong learning; structures that are proportional to the real needs of professional life and help individuals to fulfill, rebuild and develop knowledge they need throughout their lives. The lifelong learning model presented by experts of entrepreneurship is a combination of all approaches and models that can be utilized in universities to lead students to being entrepreneurs (Garvin, 2000, quoted in Kochekey, 2012).

The term entrepreneurship has been taken into consideration by researchers since the 1960s. Richard Cantillon has coined the terms entrepreneur and entrepreneurship, and has introduced them into economic jargon. The word entrepreneurship has a French root (Entereprendr), which means initiating, commencing or committing (Templer \& Cawsey, 1999). Webster's Dictionary defines the term entrepreneur as someone who is committed to organizing and managing and assuming the risks of a business or enterprise (Araste, 2004). The entrepreneur is someone who is the creator of change and dynamism, and leads markets to imbalance by affecting them.Entrepreneurship is a process of integration of knowledge, information cumulating, innovation, creativity, discovery, development, movement, activity, risk-taking and profit-making (Arasti, Fathi, \& Gholipour, 2012). Entrepreneurship is a long-term educational and training process that requires planning in the country's educational system, especially at universities and higher education institutions (Zahiri \& Turani, 2008).

Several studies have been conducted over the past years to find out about the characteristics and attributes that affect the success or failure of entrepreneurs, some of which are related to psychological factors (risk-taking, a need and desire for progress, foresight, tolerance of ambiguity, and independence); situational factors (economic, social, cultural, political and technological factors); and structural factors (all elements, physical and cultural factors and organizational resources that can affect entrepreneurial activities) (Nouri, 2011).

Traits that have been taken into consideration about entrepreneurs are as follows: 1. Need for success: a tendency to work with respect to excellent standards, in order to be successful in competitive situations. 2. Self-control: entrepreneurs believe in themselves and consider themselves the main factor leading to their failures and developments. 3. Risk-taking: The entrepreneur acts in a risk-taking approach, and does his/her best to change the risky potentials in his/her favor. 4 . The need for independence: the main characteristic trait of an entrepreneur is domination within oneself, which means that one feels that s/he is ruling his/her own destiny. 5. Creativity: the ability to develop new ideas that lead to new services or products (Carland et al., 1998). 
Schultz considers entrepreneurship as human capital, which like other capital can be raised through education, training, experience, health care, and the like.Human capital is a force that is activated in an individual, and increases his/her ability and potentiality to produce goods and services which brings about welfare for him/her in his/her personal and social life (quoted in the Dehmardeh Qal'aleno, Fatant-Fard Haghighi, \& GharayPour, 2015). The quality of education and research is among the concerns that academic systems have always struggled to achieve.In recent decades, significant efforts have been made to continuously improve the quality of higher education and achieve the objectives of academic systems (Bazargan, Fath-Abadi, \& Ainhallahi, 2010).

According to Gorman (1997), we can teach entrepreneurship, or at least develop and expand it with the help of education. Considering university's commodities such as human capital, in the form of students and faculty members, it's a good place for knowledge-based innovation. So universities can be the source of entrepreneurship, as they are the most notable reference for the production and dissemination of knowledge. Universities can be effective in promoting entrepreneurial activities in various ways, for example in the way they design the curricula of educational programs to familiarize students directly with the work (Kordnaij \& Shahab al-Din, 2003). Several factors are involved in training students as entrepreneurs, one of which is undoubtedly the quality of higher education.

In the field of higher education, there is no consensus on quality, and the main source of disagreement is due to the difference in its basics, along with its philosophical foundations. The most important difficulty in defining the quality of higher education is due to cultural issues and the issue of autonomy of universities in developing science, and also the issue of controlling the organization (Häyrinen-Alestalo \& Peltola, 2006). The quality in higher education is a special state of the system, which is the result of a series of specific actions and operations to meet specific social needs at a specific time and place (Shobeiri \& Shamsi-Papkiade, 2015). Necessities as diverse financial resources, development of necessary infrastructure for remote learning and distance education, development of the quality of the system of evaluation and admission, the quality of human resources and the faculty, the institutionalization of evaluation and validation, and last but not the least the three-way interaction of the university, firm and government, are among the factors influencing the quantitative and qualitative improvement of education in universities (Frostock, 2008).

The skills of individuals are among the acquired qualities that higher education can develop through education, during which, it causes growth and development of entrepreneurship through developing entrepreneurial attributes and increasing managerial and entrepreneurial abilities of individuals. Higher education can increase opportunities available in the market and promote the demand for entrepreneurship, through an accumulation of knowledge (Shah-Hosseini, 2010). Universities and educational institutions can present their education in a variety of ways, each of which is particular for its desired 
purpose. For this reason, considering the importance and continuity of knowledge and skills in entrepreneurship and professional development, lifelong learning is important.

In the 21st century, university officials and those who design educational curriculum have to do their best, since in the present age the most important task of the university, especially in an undergrad level, is to provide the necessary context for realizing the notion of lifelong learning; the university must nurture lifelong learners in addition to providing varied and numerous learning opportunities for them (Candy, Crebert, \& O’leary 1994). Lifelong learning means the acquisition of new skills and capabilities along with investing on one's own. Life-long learning is known as learning how to nurture, learn throughout life, learning without choice, and self-directing or self-supporting learning that has no boundaries (Brahmi, 2007). Slavin has considered lifelong learning as a tool to fulfill recently developed and emerging expectations and needs.The goal of lifelong learning is to survive in a tumultuous stressful world and to adapt oneself to the environment, along with an improvement in the quality of one's life (Afzalnia, 2013). Also, individuals with this type of learning can potentially develop their latent potential (Demirel, 2009). In lifelong learning, instead of concentrating on a monotonic learning at a certain time of life and implementing the acquired knowledge for the rest of one's life, one is bound to have an acute sense and look for the possibilities of learning throughout life, so that a person can adapt to the daily necessities of life, and along with it provides the livelihoods. Lifelong learning has a close relationship with two concepts of informal and personal learning (Dave, 1973).

Lifelong learning has the slogan of learning from cradle to grave, and is among the principles that provide learners with the skills and capabilities necessary for continuous self-education when formal education is no longer in place (Saeed \& Zare, 2013). Everyone should be a lifelong learner. The reasons are as follows: 1 . Lifelong learning increases the chance to access to the diligent workforce, and as a result, it brings about economic development; 2. Lifelong learning leads to the development of the capabilities and satisfaction of workers and as a result fosters the individual; 3 . Lifelong learning fosters principled citizenship, social integration and, as a result, social development (Nasr, Karimi, \& Baghrerian, 2006). One of the most notable models of entrepreneurship education that has been presented so far is the lifelong learning model. This model is a synthesis of all the approaches and models provided by entrepreneurial researchers so far, a combination of all behavioral, environmental and organizational approaches, each of which has led to the emergence of models in their own time (Ahmad Pourdariyany \& Matlabi, 2011).

In order to bring about an advancement of sustainable economic and social development, Iranian government needs to adopt more innovations in the field of education, nurturing human resources that are of high quality, and fostering citizens that take participation; citizens who have the right kind of skills for living properly, and have social and entrepreneurship capacities, and are ready to take on social responsibilities and tackle difficulties with their creativity. The Ministry of Education, in respect of these 
matters, organized a national training workshop on the modern concepts and systems of lifelong learning. The main objective of this workshop is to strengthen the capacity of leading policymakers and researchers that are influenced by these policies at a national level to formulate and implement new policies and strategies that enhance the lifelong learning system and makes it available for all (National Workshop on Training New Concepts and Systems in the Field of Lifelong Learning, 2012).

Lotfi (2009) inhisstudy "Investigating the impact of higher education on increasing entrepreneurial activities of graduate students", found that the difference between gender and entrepreneurial activities and the extent of these differences between various disciplines was significant in some cases. Also, Chavoshi, Farahani \& Goudarzi (2010) in their study "The Role of Physical Education M.A Textbook Content and its Supplementary Books Content in Providing Entrepreneurial Skills for Graduate Students in View of Employees" found that between the courses of master's degree in physical education and technical skills of entrepreneurship was a significant relationship. Nasr, Karimiand Baghrerian (2006) in their qualitative research Necessary Resources and Educational-research Services to Achieve Lifelong Learning, concluded that employing tools and resources to teach and familiarize students with the way they should work with them, is inevitable to help them achieve lifelong learning. Mohammadi Mehr, Maleki \& Nojomi (2016) in their qualitative research titled, "The Explanation of Teaching-learning Processes in the General Medical Curriculum with Lifelong Learning", concluded that appropriate teaching-learning methods for the development and enhancement of lifelong learning competencies in general medicine curriculum should be based on a learner-centered approach.

Considering the importance of the quality of higher education at the University of Birjand, which is among the A-rated universities in Iran, so far no research has been done on the quality of education at this university, and as a result, this research is vital. Based on the theoretical foundations and research background available on the quality of higher education as well as lifelong learning, the author believes ina creation and development of entrepreneurship in students is quite achievable.Despite the importance of the quality of higher education and making students able to learn in a lifelong learning pattern so as to be future entrepreneurs, based on the findings by the writers, so far limited research has been done in this respect, so this research seeks to answer this fundamental question: Whether the quality of higher education and lifelong learning can develop student entrepreneurship competencies?

\section{Research Method}

This research, with respect to its aim, is applied research, and it's a descriptive research, which has been done by correlation method. The statistical population of this research is 
all undergraduate students at Birjand University, who were students in the academic year 2015-2016. According to the statistics that Statistical Center of the University of Birjand has declared, the number of undergraduate students was 6637, with respect to the Krejcie and Morgan's table, a sample size of 361 people were selected. To do this research, random sampling was used.To collect the required data from the sample, three questionnaires have been employed as follows: Liberal Entrepreneurship Competency Questionnaire

To assess entrepreneurship competencies, Liberal questionnaire (2007) with 55 questions was employed. The questionnaire has three components: success, planning, and strength. The response rate of the questionnaire is a 5-point Likert scale $(1-$ never, 2 - at least, 3 - sometimes, 4 - usually, 5 - always). Construct validity of this questionnaire was investigated using exploratory and reliability factor analysis using Cronbach's alpha. In order to do an exploratory factor analysis of entrepreneurship competencies and its components, Bartlett's Sprite test was utilized.The results of Bartlett's test of sphericity is equal to 6159.96 and the significance level is $\mathrm{P}<0.01$, so the zero hypothesis, which states that the correlation matrix is an identity matrix, is rejected. The KMO measure of sampling capability is equal to 0.897 , which indicates that the sample size is sufficient for sampling, and the KMO is better as itis closer to one.

\section{Mantz Questionnaire of Quality in Higher Education}

To assess the quality of university education, the Standardized Questionnaire of Mantz (1995), which contains 30 questions, has been used.This questionnaire measures these 9 sub-scales: helping students to learn, reaching minor goals, understanding the needs of students and others who work in the field of education, valuing individuals, leadership and communication, supporting operations, measuring effectiveness, planning for improvement, and building collaborative relationships. The accountability scale of the Likert Spectrum Questionnaire is on 5 points: very low (1) to very high (5). The construct validity of this questionnaire was verified by using confirmatory and reliability factor analysis using Cronbach's alpha. The Bartlett's test of sphericity was used to perform exploratory factor analysis, and the results of the Bartlett's test were 3906.39 and the significance level was $\mathrm{P}<0.01$, so the zero hypothesis, which states that the correlation matrix is an identity matrix, is rejected. In the present factor analysis, the KMO ratio was 0.919 which indicates the suitability of the sampling scale.

\section{Lifelong Learning Questionnaire of Wielkiewicz and Meuwissen}

To assess the lifelong learning competencies, Wielkiewicz and Meuwissen's questionnaire (2014) which is a single-component one and contains 16 questions has been employed. The response rate of this questionnaire is a 5-point Likert scale ( 1 - never, 2 - rarely, 3 - sometimes, 4 - often, 5 - always). Nasrollahi (2016) assessed the validity of the lifelong learning questionnaire using factor analysis and the root mean square error of estimate 1 (0.71) and the index of goodness of fit 2 and indices of fit 3 were (0.94) and 
(0.96) respectively, and the reliability of the questionnaire was reported using Cronbach's alpha (0.82).

\section{Results}

In order to determine the appropriate statistical test for examining hypotheses and the possibility of using parametric statistics, Kolmogorov-Smirnov test was used for data normalization. The results of the Kolmogorov-Smirnov test show that the assumption of normalization for all variables of the research can be verified ( $Z$ statistic of entrepreneurship competencies, 0.75 at the significant level of $0.62, Z$ statistic quality of higher education, 0.94 at the significance level of 0.33 , and $\mathrm{Z}$ statistic of lifelong learning, 0.99 at the significant level of 0.27 ); therefore, the assumption of the normalization of some variables is confirmed.

1. What is the condition of entrepreneurial competencies among undergraduate students of Birjand University?

Table 1

One sample T-test of entrepreneurship competency components

\begin{tabular}{lcccccc}
\hline \multirow{2}{*}{$\begin{array}{c}\text { Variable } \\
\text { name }\end{array}$} & T Value & df & sig & $\begin{array}{c}\text { Differences in } \\
\text { mean }\end{array}$ & \multicolumn{2}{c}{ 95\% CI } \\
Lower & Upper \\
\hline Success & 16.44 & 354 & 0.001 & 0.39 & 0.34 & 0.44 \\
\hline Planning & 12.53 & 354 & 0.001 & 0.33 & 0.28 & 0.38 \\
\hline Power & 15.97 & 354 & 0.001 & 0.38 & 0.33 & 0.43 \\
\hline
\end{tabular}

To compare the mean scores of entrepreneurship competencies and their components with a theoretical mean (3), one sample t-test was used. As shown in Table 1, the result of this test is significant, that is, there is a significant difference between the theoretical mean and the calculated mean for entrepreneurial competencies and its components. Therefore, we can conclude that the mean components of entrepreneurial competencies are higher than mean limit and are in a favorable condition.

2. What is the quality of higher education among undergraduate students at Birjand University? 
Table 2

One sample T-test of quality of higher education and its components

\begin{tabular}{|c|c|c|c|c|c|c|}
\hline \multirow{3}{*}{ Variable name } & \multicolumn{6}{|c|}{ Theoretical Mean $=3$} \\
\hline & \multirow{2}{*}{ T Value } & \multirow[t]{2}{*}{ df } & \multirow[t]{2}{*}{ sig } & \multirow{2}{*}{$\begin{array}{l}\text { Differences } \\
\text { in mean }\end{array}$} & \multicolumn{2}{|c|}{$95 \% \mathrm{CI}$} \\
\hline & & & & & Lower & Upper \\
\hline Helping students to learn & -11.32 & 351 & 0.001 & -0.44 & -0.52 & -0.36 \\
\hline Reaching minor goals & -7.61 & 350 & 0.001 & -0.29 & -0.37 & -0.21 \\
\hline $\begin{array}{l}\text { Understanding the needs of students } \\
\text { and others who work in the field of } \\
\text { education }\end{array}$ & -7.86 & 350 & 0.001 & -0.30 & -0.37 & -0.22 \\
\hline Valuing individuals & -8.47 & 350 & 0.001 & -0.32 & -0.40 & -0.24 \\
\hline Leadership and Supporting & -10.66 & 350 & 0.001 & -0.37 & -0.44 & -0.30 \\
\hline Measuring effectiveness, and planning & -10.70 & 350 & 0.001 & -0.34 & -0.40 & -0.28 \\
\hline Building collaborative relationships & -12.65 & 350 & 0.001 & -0.47 & -0.54 & -0.39 \\
\hline
\end{tabular}

To compare the mean scores of higher education quality and its components with theoretical mean (3), one sample t-test was employed. As shown in Table 2, the result of the test is significant and because the quality of the components of higher education has a lower mean than the theoretical mean;therefore, it can be concluded that the quality of higher education and its components are not in a favorable condition.

3. What are the levels of lifelong learning competencies among undergraduate students at Birjand University?

Table 3

One-sample t-test for lifelong learning

\begin{tabular}{lcccccc}
\hline \multirow{2}{*}{ Variable name } & \multicolumn{7}{c}{ Theoretical Mean $=3$} \\
\cline { 2 - 7 } & T Value & df & sig & Differences in & \multicolumn{2}{c}{ 95\% CI } \\
& & & & Lower & Upper \\
\hline Lifelong learning & 7.89 & 353 & 0.001 & 0.26 & 0.19 & 0.32 \\
\hline
\end{tabular}

In Table 3, the results of one sample t-test are presented for the life-long learning variable. According to this table, which is compared with the theoretical mean (3), the test is significant, meaning there is a significant difference between the theoretical mean and the calculated value for the lifelong learning variable; Therefore, it can be concluded that lifelong learning is in a favorable condition.

Hypothesis 1: The components of quality of higher education are predictors of entrepreneurship competencies of undergraduate students at Birjand University. 


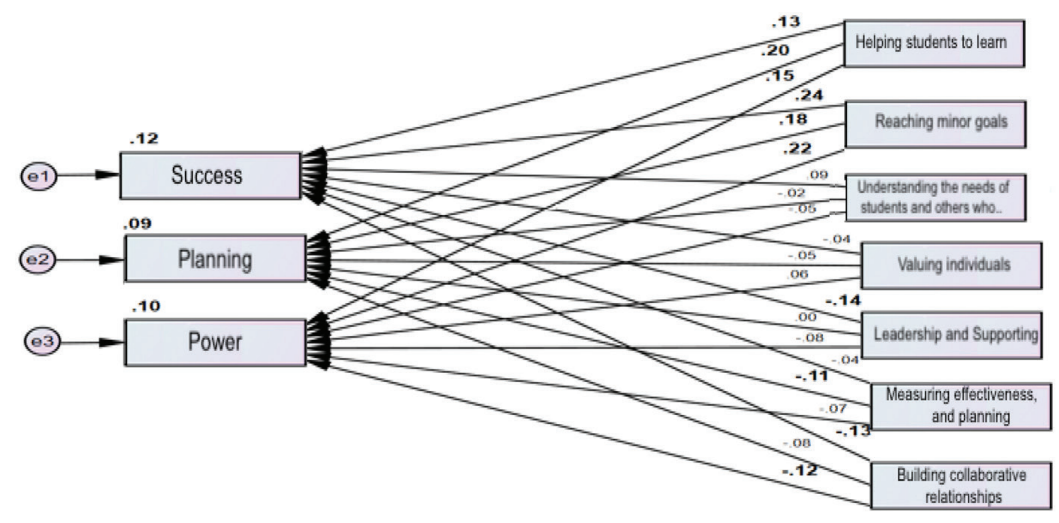

Figure 1. Path Coefficient of Components of Quality of Higher Education and Components of Entrepreneurship Competencies

Table 4

Regression Weight Analysis of the Model

\begin{tabular}{lcccc}
\hline & $\begin{array}{c}\text { Non-standar- } \\
\text { dized regression }\end{array}$ & $\begin{array}{c}\text { Standard } \\
\text { error }\end{array}$ & beta & Sig. \\
\hline $\begin{array}{l}\text { Understanding the needs of students and others who } \\
\text { work in... } \rightarrow \text { Success }\end{array}$ & 0.59 & 0.032 & 0.093 & 0.064 \\
\hline Valuing individuals $\rightarrow$ Success & -0.023 & 0.032 & -0.036 & 0.472 \\
\hline Leadership and support $\rightarrow$ Success & -0.098 & 0.035 & -0.0139 & 0.005 \\
\hline Help students to learn $\rightarrow$ Planning & -0.098 & 0.035 & 0.195 & 0.001 \\
\hline $\begin{array}{l}\text { Understanding the needs of students and others who } \\
\text { work in.. } \rightarrow \text { Planning }\end{array}$ & -0.014 & 0.036 & 0.019 & 0.702 \\
\hline $\begin{array}{l}\text { Understanding the needs of students and others who } \\
\text { work in.. } \rightarrow \text { Educational power }\end{array}$ & -0.030 & 0.032 & 0.047 & 0.354 \\
\hline Valuing individuals $\rightarrow$ Planning & -0.034 & 0.036 & 0.048 & 0.343 \\
\hline Valuing individuals $\rightarrow$ Power & 0.037 & 0.032 & 0.057 & 0.260 \\
\hline Leadership and support $\rightarrow$ Planning & 0.003 & 0.040 & 0.003 & 0.948 \\
\hline Leadership and support $\rightarrow$ Power & -0.057 & 0.036 & -0.081 & 0.108 \\
\hline Measuring Effectiveness and Planning $\rightarrow$ Planning & -0.089 & 0.043 & -0.105 & 0.039 \\
\hline Building collaborative relationships $\rightarrow$ Planning & -0.059 & 0.037 & -0.081 & 0.113 \\
\hline Helping students to learn $\rightarrow$ Success & 0.078 & 0.031 & 0.125 & 0.012 \\
\hline Helping students to learn $\rightarrow$ Power & 0.095 & 0.032 & 0.151 & 0.003 \\
\hline Reaching minor goals $\rightarrow$ Success & 0.150 & 0.032 & 0.238 & 0.001 \\
\hline Reaching minor goals $\rightarrow$ Planning & 0.129 & 0.036 & 0.184 & 0.001 \\
\hline Reaching minor goals $\rightarrow$ Power & 0.141 & 0.032 & 0.223 & 0.001 \\
\hline Measuring Effectiveness and Planning $\rightarrow$ Success & -0.033 & 0.038 & -0.043 & 0.338 \\
\hline Measuring Effectiveness and Planning $\rightarrow$ Power & -0.050 & 0.039 & -0.065 & 0.197 \\
\hline Building collaborative relationships $\rightarrow$ Success & -0.082 & 0.033 & -0.125 & 0.013 \\
\hline \begin{tabular}{l} 
Building collaborative relationships $\rightarrow$ Power \\
\hline
\end{tabular} & -0.083 & 0.033 & -0.125 & 0.014 \\
\hline
\end{tabular}


- According to Table 4, the path coefficients of the components of the quality of higher education and the components of entrepreneurial competencies, the following results can be stated:

- The beta coefficient is between components of "Understanding the needs of students and others who work in the field of education" and "success" is (0.09) and their significance level equals (0.6), and since it's larger than 0.05 then it's not significant; The results of this table also indicate that the beta coefficient between "Understanding the needs of students and others who work in the field of education with planning" equals (0.01), with a significance level of $(0.70)$, and since this value is also larger than 0.05 , it's not significant; And the beta coefficient of this component with power is $(0.04)$, with a significance level of (0.35), which is due to the fact that it is larger than 0.05 , but it is not significant.

- The beta coefficient is between the components of "valuing individuals and success" is $(-0.03)$ and their significance level equals $(0.47)$, and since it is larger than 0.05 , it's not significant; Also, the results of this table indicate that the beta coefficient between valuing of individuals and planning is (0.04), with a significance level of $(0.34)$, and since it is larger than 0.05, it's not significant; And the beta coefficient of this component with power is $(0.05)$ with a significance level of $(0.26)$, and since it is larger than 0.05 , it's not significant.

- The beta coefficient between the components of "leadership and support and success" is $(-0.03)$ and their significance level equals (0.005), and since it is less than 0.05 , it is significant; Also, the results of this table indicate that beta coefficient between leadership and support and planning is equal to (0.003), with a significance level of (0.94), and since it is larger than 0.05 , it's not significant; And the beta coefficient of this component with power is $(-0.08)$, with a significant level of $(0.11)$, and since it's larger than 0.05 , it is not significant.

- The beta coefficient between the components of "Helping students to learn and planning" is (0.19) and their significance level equals (0.001), and since it is less than 0.05 , it's significant; And the beta coefficient between helping students to learn and success equals (0.12) with a significance level of (0.01), and since it's also less than 0.05 , it's significant; and the beta coefficient of this component with power is (0.15), with a significance level of (0.003), which is significant since it is less than 0.05 .

- The beta coefficient between the components of "Measuring effectiveness and planning" and "planning" is (-0.10) and their significance level equals (0.03), and since it's smaller than 0.05 it's significant; also, the results of this table indicate that the beta coefficient between "Measuring effectiveness and planning" and "success" equals (-0.04), with a significance level of (0.38), and since it is larger than 0.05 , it is not significant; and the beta coefficient of this component with power is $(-0.06)$ with a significance level of (0.19), and since it is larger than 0.05 , we conclude that it is not significant.

- The beta coefficient between the components of "building relationships based on collaboration and success" is (-0.12) and their significance level equals (0.01), and since 
it is less than 0.05 , it's significant; and the results of this table indicate that the beta coefficient between the establishment of collaborative relationship and power is $(-0.12)$, with a significance level of (0.01), and since it is less than 0.05 , it's significant; and the beta coefficient of this component with planning is $(-0.08)$, with a significant level of $(0.11)$, and since it's larger than 0.05 , it's not significant.

- The beta coefficient between the components of "reaching minor goals and success" is $(0.23)$ and their significance level equals $(0,001)$, and since it's less than 0.05 , so it's significant; and the results of this table indicate that the beta coefficient between achieving the goals and planning equals (0.18), with a significance level of (0.001) and since it's less than 0.05 , it's significant; and the beta coefficient of this component with power is (0.22), with a significance level of (0.001), that since it's less than 0.05 , we conclude that it is significant.

Second hypothesis: Lifelong learning is predictive of the entrepreneurial competency of undergraduate students at Birjand University.

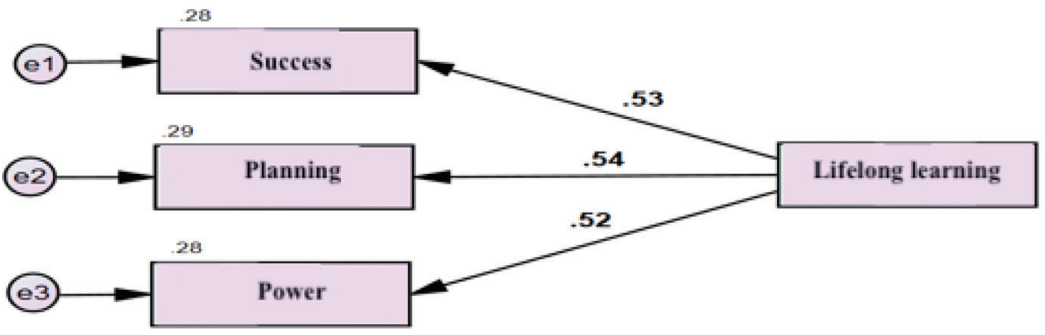

Figure 2. The Path Coefficient of Lifelong Learning and the Components of Entrepreneurial Competencies

Table 5

Regression Weight Analysis of the Model

\begin{tabular}{lcccc}
\hline & $\begin{array}{c}\text { Non-standardized } \\
\text { regression }\end{array}$ & $\begin{array}{c}\text { Standard } \\
\text { error }\end{array}$ & beta & Sig. \\
\hline Lifelong learning $\rightarrow$ Success & 0.385 & 0.032 & 0.534 & 0.001 \\
\hline Lifelong learning $\rightarrow$ Planning & 0.433 & 0.036 & 0.538 & 0.001 \\
\hline Lifelong learning $\rightarrow$ Power & 0.382 & 0.033 & 0.525 & 0.001 \\
\hline
\end{tabular}

- The beta coefficient between "lifelong learning and success" is ( 0.53$)$ and their significance level equals (0.001), and since it is less than 0.05 , so it's significant. Also, the results of this table indicate that the beta coefficient between lifelong learning and planning is (0.53), with a significance level of (0.001), and since it is less than 0.05 , it's significant. 
And the beta coefficient of this component with power is (0.52), with a significance level of (0.001), and since it is also less than 0.05 , it's significant.

\section{Discussion and Conclusion}

This study aimed to investigate the role of quality in higher education and lifelong learning competencies in entrepreneurship competencies of undergraduate students at the University of Birjand. The results of the present research, with respect to the first research question, show that in the sample group, the mean of all components of entrepreneurial competencies (success, planning and power) of undergraduate students of Birjand University is higher than the theoretical mean, with a value of (3). The results of this research are in accordance with the findings of Farahani and Falahahti (2007), Hezar-Jaribi (2003), Zali, Mehdochi and Kordnaij (2007), Chi Kuo (1996), and Guerrero, Rialp, and Urbano (2008). In these researches, as the present study, the sample group evaluated the condition of entrepreneurial competences higher than the theoretical mean. But in another study, done by Safari and Samiyazadeh (2012), the condition of entrepreneurial competences is more adverse than the theoretical mean, which is not consistent with the findings of the present study.

Also, the results of the research show that in the sample group, the mean of all components of the quality of higher education among undergraduate students of Birjand University is lower than the theoretical mean level, which is (3). Meanwhile, the highest mean was related to the "reaching minor goals" with the value (2.70) and the lowest mean was for the component "building cooperative relationships" with the value (2.52). Although all of the quality components of higher education are significant at $95 \%$ confidence interval, but because the mean of all components is less than the theoretical mean level, the quality of higher education of undergraduate students at Birjand University, is not in a favorable condition. As stated above, the component of "reaching the minor goals" is at the highest level. The high degree of undergraduate students' goals realization at Birjand University can be the result of university's consideration of appropriate sub-goals for achieving the main ones, but the unfavorable condition of the component "building cooperative relationships" can be explained as such: Mantz states that this component is related to studying the internal and external relations of the university and individuals' cooperation in the realization of the university's mission; therefore, the poor condition of cooperation-based relationships among undergraduate students at Birjand University can be due to University's placing too much emphasis on the rules and regulations, as well as a lack of a working group consisting of both students and professors, and their emphasis on working on their own. Therefore, considering that the quality of higher education at Birjand University is lower than the theoretical mean, so if the university wants to succeed in its confronting challenges and issues, its education management should put more 
emphasize on the quality of education; To this end, it's necessary to reform strategies and programs of the university and put them in accordance with the needs and expectations of the students and the community, and pay attention to the needs of the labor market and the employment condition of the students, when planning and developing the fields of education and their capacities (Kordnaij \& Shahab al-Din, 2003).The results obtained from this research question are in accordance with the research findings of Shobeiriand Shamsi-Papakidadeh (2015), Hadi, Rezapur and Salman-Pour (2017), Yadeghare et al. (2013), and Voss et al. (2007).

The results of the research on the third question show that in the sample group, the mean value of lifelong learning among undergraduate students at Birjand University is (3.26) which is higher than the mean theoretical level, with a value of (3); and also, from a statistical point of view, lifelong learning is at a confidence interval of $95 \%$; therefore, we can say that the life-long learning condition of undergraduate students at Birjand University is favorable. The results of this research question is in accordance with the research findings of Nasr, Karimi and Baghrerian(2006), and Brooks and Everett (2008).

According to the results obtained from the first hypothesis, the component of the quality of higher education have a significant relationship with some components of entrepreneurship competencies, and doesn't have with some others, and are not able to predict students' entrepreneurship competencies. Chraghchashm (2007), Hosseini (2007) and Saeedi Mehrabad and Mohtadi (2008) in their research found that there is a positive and significant relationship between the quality of higher education and entrepreneurship competencies. But Chavoshi, Farahani and Goodarzi (2010) found that there was no significant relationship between the quality of higher education and entrepreneurship competencies. Also, the results obtained from the second hypothesis show that there is a positive and significant relationship between lifelong learning and entrepreneurship competencies. The results of this research are in consistence with the research results of Sharifi-Zadehand Abdollahzadeh (2012), Hossein-Nasab, Khadivi and Moosa-Zadeh (2010) and Nasrollahi (2016).

\section{References}

Afzalnia, M. R. (2013). Design and Acquaintance with Material Centers and Learning Resources.

Tehran: Organization for the Study and Compilation of Humanities Books of Universities (samt).

Ahmad Pourdariani, M., \& Motlabe, M. (2011). Provide a Lifelong Learning Model of Entrepreneurship with a Consolidated Approach (provided by the Entrepreneurship Education Consortium). Work and Society, Social, Economic, Scientific and Cultural Monthly, 134(16), 21-37. 
Arasteh, H. R. (2004). Entrepreneurship and Higher Education (Principles and Barriers). Approach Quarterly, 13(29), 28-33.

Arasti, Z., Fathi, F., \& Gholipour, A. (2012). Characteristics of Personality Affecting Social Entrepreneurial Intent in Economic Entrepreneurs. Journal of New Economics and Trade, 28(7), 153-173.

Bazargan, A., Fathabadi, G., \& Ainhallahi, B. (2010). An Appropriate Internal Assessment Approach to Continually Improve the Quality of Educational Departments in Medical Universities. Journal of Psychology and Educational Sciences (Faculty of Psychology and Educational Sciences, University of Tehran), 5(2), 7-26.

Brahmi, F. A. (2007). Medical Students' Perception of Lifelong Learning at Indiana University School of Medicine. Pro Quest.

Brooks, R., \& Everett, G. (2008). The Impact of Higher Education on Lifelong Learning. International Journal of Lifelong Education, 27(3), 239-254.

Candy, P. C., Crebert, G., \& O'leary, J. (1994). Developing Lifelong Learners through Undergraduate Education (Vol. 28). Canberra: AGPS.

Carland, J. W., Hoy, F., Boulton, W. R., \& Carland, J. A. C. (1998). Differentiating Entrepreneurs from Small Business Owners: A Conceptualization. Academy of management review, 9(2), 354-359.

Chavoshi, Z., Farahani, A., \& Goodarzi, M. (2010). The Role of Curriculum and Master's Degree Support in Providing Graduates Entrepreneurship Skills from Employers' Point of View. Researches in Sport Sciences, 7(8), 13-152.

Chi Kuo, H. (1996). Testing Hypotheses of Entrepreneurial Characteristics: A Study of Hong Kong MBA Students. Journal of managerial Psychology, 11(3), 12-25.

Chraghchashm, A. (2007). The Effect of Teaching Methods Based on Creativity Techniques in Teaching and Studying. Islamic Educational Quarterly, 5(3), 7-36.

Dave, R. H. (1973). Lifelong Education and School Curriculum. UIE Monographs 1.

Dehmardeh Qal'aleno, S., Fatant-Fard Haghighi, M., \& Gharay-Pour, R. (2015). Examining Entrepreneurship Training Models. First Conference on Management and Entrepreneurship in Resistance Economics.

Demirel, M. (2009). Lifelong Learning and Schools in the Twenty-first Century. Procedia-Social and Behavioral Sciences, 1(1), 1709-1716.

Farahani, A., \& Falahati, M. (2007). Investigating the Relationship between Psychological Factors of Empowerment and Organizational Entrepreneurship among Staffs of Educational Institutions of Universities. Journal of Research in Sport Sciences, 15(5), 67-79.

Frostock, M. (2008). Future Thinking about Quality in Iran's Higher Education; A Model Based on Basic Theory (GT). Quarterly Journal of Research and Planning in Higher Education, 50(14), 67-96.

Gorman, G., Hanlon, D., \& King, W. (1997). Some Research Perspectives on Entrepreneurship Education, Enterprise Education and Education for Small Business Management: a Ten-year Literature Review. International SmallBusiness Journal, 15(3), 56-77. 
Guerrero, M., Rialp, J., \& Urbano, D. (2008). The Impact of Desirability and Feasibility on Entrepreneurial Intentions: A Structural Equation Model. International Entrepreneurship and Management Journal, 4(1), 35-50.

Hadi, R., Rezapour, Y., \& Salmanpour, S. (2017). Higher Education Quality Measurement Indicators Based on the Kano Model at Urmia University. Educational and Evaluation Journal, 34 (9), 35-50.

Häyrinen-Alestalo, M., \& Peltola, U. (2006). The Problem of a Market-oriented University. Higher Education, 52(2), 251-281.

Hezar-Jaribi, J. (2004). Graduates Entrepreneurship Development. Quarterly journal of research and planning in higher education, 4 (9),159-169.

Hossein-e Nasab, D., Khadivi, A., \& Moses-Zadeh, A. (2010). Investigating the Relationship between the Components of a Learning Organization and the Students' Entrepreneurship Attitudes of Payame Noor University in Naghadeh in the academic year 2009-2010. Journal of Education and Evaluation (Sciences), 12(3), 29-46.

Hosseini, A. S. (2007). Investigating the Effect of Teachers' Creativity Training Program on Academic Achievement and Student Self-Concept Creativity. Quarterly Journal of Educational Innovations, 23(6), 148-168.

Karimi, S., Nasr Esfahani, A. R., Baghretian, K. (2006). Resource and Research Services Required by the University to Realize Lifelong Learning. Quarterly Journal, 1(17), 163-184.

Kochekey, L. (2012). Investigating the Relationship between the Key Factors of an Innovative University and Students' Orientation to Lifelong Learning: A Case Study of Shiraz University. Master's Degree in Educational Management, Faculty of Psychology and Psychology, Shiraz University.

Kordnaij, A., \& Shahab al-Din, Sh. (2003). The Role of Higher Education in the Development of Entrepreneurship and Job Creation in the Country. Proceedings of the First Conference on Employment and Higher Education, Tehran: Publishing Organization Jihad University of Tarbiat Modares University.

Liberal, A. E. (2007). Appraising and Developing Yourself for an Entrepreneurial Career. (Eds.) Maghirnf, T., Librando, P., Esguerra, D., \& Recio, D. In introduction to Entrepreneurship (pp. 41-43). Quezon City: Small Enterprises Research and Development Foundation, Inc. in cooperation with UP-ISSI.

Lotfi, M. (2009). Investigating the Impact of Academic Education on Increasing Entrepreneurship Activities among Students of Payame Noor Universities of Mazandaran Province. Thesis disserted, Department of Educational Sciences, Payame Noor University of Mazandaran.

Mantz, Y. (1995). Self-scrutiny of Quality in Higher Education: a Questionnaire. Quality Assurance in Education, 3(1), 10-13.

Mohammadi Mehr, M., Maleki, H., \& Najumi, F. (2016). Explaining Teaching-learning Processes in General Medical Curriculum with Lifelong Learning. Journal of Medical Education Strategies, 7(3), 181-189. 
Nasr, A. R. Karimi, S., \& Baghrerian, K. (2006). Resource and Research Services Required by the University to Realize Lifelong Learning. Journal of National Library Studies and Information Organization, 65(17), 163-184.

Nasrollahi, R. (2016). The Role of Intellectual Capital in the Entrepreneurial Characteristics of Tire Desert Factory Employees in Birjand City. Unpublished Master's Thesis. Birjand University, Faculty of Education and Psychology.

National Workshop on New Concepts and Systems in Lifelong Learning (2012). National Workshop Final Report. Tehran.

Nouri, H. R. (2011, April 1). Entrepreneurship from the Perspective of Various Economics Schools. Retrieved from Iranian Entrepreneurs House.www Karafariny.com

Saeed, N., \& Zare, H. (2013). Advanced Teaching Method. Tehran: Payame Noor Publications.

Saeedi Moherabad, M., \&Mohtadi, M. M. (2008). The Effect of Entrepreneurship Education on the Development of Entrepreneurial Behaviors (Case Study: Entrepreneurship Education, Ministry of Labor and Social Affairs). Entrepreneurship Development Journal, 2(1), 57-73.

Safari, S., \& Samiyazadeh, M. (2012). Needs Assessment of Knowledge Training and Entrepreneurship Skills in Humanities. Journal of Educational Technology, 1(7), 65-79.

Segal, G., Borgia, D., \& Schoenfeld, J. (2005). The Motivation to Become an Entrepreneur. International journal of Entrepreneurial Behavior \& research, 11(1), 42-57.

Shah Hassani, A. (2010). Entrepreneurship. Tehran: AYJ Publishing.

Sharifi-Zadeh, A., \& Abdollahzadeh, Gh. H. (2012). The Relationship between Learning Style and Entrepreneurial Characteristics of Agricultural Students. Quarterly Journal of Research and Planning in Higher Education, 18(64), 131-152.

Shobeiri, M., \& Shamsi Papakidae, Z. (2015). In-depth Qualitative Assessment of the Master's Degree Curriculum from the Point of View of Professors, Students and Educational Experts at Pajou Noor University. Journal of Research, School and Virtual Learning Research, 9(3), 83-94. Slavin, R. E., Cheung, A., Groff, C., \& Lake, C. (2008). Effective Reading Programs for Middle and High Schools: A Best-Evidence Synthesis. Reading Research Quarterly, 43(3), 290-322.

Templer, A. J., \& Cawsey, T. F. (1999). Rethinking Career Development in an Era of Portfolio Careers. Career Development International, 4(2), 70-76.

Voss, R., Gruber, T., \& Szmigin, I. (2007). Service Quality in Higher Education: The Role of Student Expectations. Journal of Business Research, 60(9), 949-959.

Wielkiewicz1, R. M. \& Meuwissen, A. S. (2014). A Lifelong Learning Scale for Researchand Evaluation of Teaching and Curricular Effectiveness. Teaching of Psychology, 41(3), 220-227. Yadeghare, F., Ashtari, A., Mehdi Pour, N., Jafari, N., Simaashirazi, T., Rafiei Alwavejh, M., Zarifian, Talaee; D. A., Abazari, Z., \& Farazi, M. (2014). Internal Evaluation of Speech Therapy Group. Journal of Pathology of Speech and Language, 1(1), 29-36.

Zahiri, M., \& Turani, S. (2008). Providing a Model for Setting Up Entrepreneurship Centers in Medical Universities. Quarterly Journal of Research and Planning in Higher Education, 14 (1), 1-18. 


\title{
Aukštojo mokslo kokybès ir mokymosi visą gyvenimą vaidmuo bakalaurų verslumo kompetencijose
}

\author{
Ali Asgari ${ }^{1}$, Hossein Shokouhi Fard ${ }^{2}$, Fatemeh Tirgoo ${ }^{3}$ \\ 1 Švietimo mokslų katedra, Edukologijos ir psichologijos fakultetas, Birjando universitetas, Birjandas, Iranas, \\ ali.asgari@birjand.ac.ir \\ 2 Švietimo mokslų katedra, Edukologijos ir psichologijos fakultetas, Birjando universitetas, Birjandas, Iranas, \\ hshokohi@birjand.ac.ir \\ 3 Švietimo mokslų katedra, Edukologijos ir psichologijos fakultetas, Birjando universitetas, Birjandas, Iranas, \\ fatemehtirgoo@gmail.com.
}

\section{Santrauka}

Pagrindinis šio tyrimo tikslas - ištirti aukštojo smokslo akademinès kokybès ir mokymosi visą gyvenimą kompetencijų vaidmenị Birjando bakalauro studijų programos studentų verslumo kompetencijose. Šio tyrimo statistinè populiacija apėmè visus 2015-2016 metu bakalauro studentus, jų skaičius buvo 6637. Taikant paprastą atsitiktinę imtį, buvo atrinktas 361 tiriamasis. Tyrimo metodas - taikomoji aprašomoji koreliacinė analizè. Duomenims rinkti buvo naudojamas liberalus verslumo kompetencijos klausimynas (2007 m.), Mantz akademinis aukštojo mokslo kokybės (1995 m.) ir mokymosi visą gyvenimą (Wielkiewicz ir Meuwisseno (2014 m.)) klausimynai. Jų patikimumas buvo apskaičiuotas Cronbacho alfa $(0,91),(0,92)$ ir $(0,82)$. Rezultatai parodè, kad verslumo ir mokymosi visą gyvenimą kompetencijos yra geros, tačiau universitetinio išsilavinimo akademinè kokybė nėra tinkama. Kai kurie universitetinio išsilavinimo akademinės kokybės komponentai turejjo reikšmingą ryši su verslumo kompetencijos komponentais. Taip pat yra pastebimas teigiamas ir reikšmingas ryšys tarp mokymosi visą gyvenimą ir verslumo kompetencijų. Ši varomoji jèga skatina kurti visa apimančius ir atliepiančius universitetus ne revoliucijai, bet labiau evoliucijai.

Esminiai žodžiai: aukštasis mokslas, mokymasis visą gyvenimą, verslumo kompetencijos.

Gauta 20190511 / Received 11052019

Priimta 20191007 / Accepted 07102019 